\title{
Isocitrate Dehydrogenase [NADP], Mitochondrial
}

National Cancer Institute

\section{Source}

National Cancer Institute. Isocitrate Dehydrogenase [NADPI, Mitochondrial. NCI

Thesaurus. Code C84990.

Isocitrate dehydrogenase [NADP], mitochondrial protein (452 aa, $\sim 51 \mathrm{kDa}$ ) is encoded by the human IDH2 gene. This protein plays a role in intermediary metabolism. 